Rev. Bras. Saúde Prod. Anim., Salvador, v.20, 01 - 12, e0152019, 2019

\title{
Ingestive behavior of sheep on Massai grass under different pre-grazing heights under rotational stocking
}

\section{Comportamento ingestivo de ovinos em capim Massai sob diferentes alturas pré-pastejo sob lotação rotativa}

\author{
CARDOSO, Rebeca Rocha ${ }^{*}$, SOUSA, Luciano Fernandes de ${ }^{2}$, FERREIRA, Ana Cristina \\ Holanda $^{2}$, NEIVA, José Neuman Miranda ${ }^{2}$, FERREIRA, Deborah Alves ${ }^{2}$, SILVA, André \\ Guimarães Maciel e $\mathrm{e}^{3}$
}

${ }^{1}$ Docente da Universidade Estadual do Tocantins, UNITINS, Palmas, TO, Brasil

${ }^{2}$ Docente da Universidade Federal do Tocantins, UFT, Araguaína, TO, Brasil.

${ }^{3}$ Docente da Universidade Federal do Pará, UFPA, Castanhal, PA, Brasil.

*Corresponding author: rebecarcardoso@outlook.com

\section{SUMMARY}

This studyaimed to assess the influence of three pre-grazing heights of Massai grass on the ingestive behavior of sheep under rotational stocking. Eighteen Dorper $\mathrm{x}$ nondescript crossbred sheep were used under rotational stocking on Massai grass at pregrazing heights. The animal stocking was estimated to ensure a reduction of approximately $50 \%$ of the initial height. Behavior assessments were performed from 6 to $18 \mathrm{~h}$ at the entrance and exit of animals from paddocks. The longest activity was grazing, followed by rumination and other activities, and the period from 6 to $10 \mathrm{~h}$ showed the longest grazing.In the other periods, the animals in the $35-\mathrm{cm}$ treatment grazed less when compared to those ofthe other treatments. Rumination in all treatments was more significant in the period from 14 to $18 \mathrm{~h}$, but the animals in the $45-\mathrm{cm}$ treatment spent more time doing this activity, which gave them a higher time of rumination of the food bolus, as well as ruminating chews. The bite rate was higher for the $25-\mathrm{cm}$ treatment, followed by the 45 and $35-\mathrm{cm}$ treatments, respectively.

Key words: Megathyrsus maximus, Panicum maximum, ruminants

\section{RESUMO}

\section{Animal Production and Environment}

Received on: 14/12/2018. Accepted on: 09/04/2019
O objetivo foi avaliar a influência de três alturas pré-pastejo do capim Massai sobre o comportamento ingestivo de ovinos sob lotação rotativa. Foram utilizados 18 ovinos mestiços Dorper x sem padrão racial definido (SPRD) sob lotação rotativa em capim Massai nas alturas pré-pastejo de 45,35 e 25 $\mathrm{cm}$. A lotação animal foi estimada para garantir a redução de aproximadamente 50\% da altura inicial. As avaliações de comportamento foram feitas das 6 às $18 \mathrm{~h}$ na entrada e na saída dos animais dos piquetes. A maior atividade de forma geral realizada foi a de pastejo, seguida de ruminação e outras atividades, sendo o período de 6 às 10 $\mathrm{h}$ o que apresentou maior atividade de pastejo. Nos demais períodos, os animais no tratamento com $35 \mathrm{~cm}$ pastejaram menos que os animais dos outros tratamentos. A ruminação, em todos os tratamentos, foi mais significativa no período das 14 às $18 \mathrm{~h}$, mas os animais no tratamento com $45 \mathrm{~cm}$ foram os que passaram maior tempo realizando esta atividade. Os animais no tratamento com 45 $\mathrm{cm}$ apresentaram maior tempo de ruminação do bolo alimentar e maior número de mastigações merícicas. A taxa de bocados foi superior para o tratamento com $25 \mathrm{~cm}$, seguido do com 45 e $35 \mathrm{~cm}$ respectivamente.

Palavras-chave: Megathyrsus maximus, Panicum maximum, ruminantes 


\section{INTRODUCTION}

Massai grass is a suitable forage for livestock activity due to its productivity and structure. It also has important characteristics for its exploitation in the meat sheep, such as low size, soil fixation, high regrowth capacity, and tolerance to intense grazing (AMORIM et al., 2017; LEMPP et al., 2001; SAMPAIO et al., 2016). Besides choosing the appropriate forage, it is necessary to assess how sheep behave among pasture management possibilities by observing the animal reaction to established defoliation limits in order to assist in the adequate definition of pasture height management.

Animal behavior is modified according to the adopted defoliation strategy, resulting from the manipulation of pasture structure when pre- and post-grazing heights are established (ZANINI et al., 2012). The study of animal behavior on pasture allows a better understanding of the interaction between animal and plants and other factors that interfere with the search and feeding process (PIAZZETTA et al., 2009), which determine animal intake. It also makes possible to observe indications of improvements in pasture quality and cost reduction in order to optimize management practices (SANTOS et al., 2011).

In this sense, this study aimed to assess the influence of three pre-grazing heights of Massai grass on the ingestive behavior of sheep under rotational stocking.

\section{MATERIAL AND METHODS}

The experiment was conducted at the Escola de MedicinaVeterinária e Zootecnia(EMVZ) of the Federal University of Tocantins (UFT), campus of Araguaína, Tocantins, between February and April 2017, during the rainy season. The procedures used in this experiment were approved by the Ethics Committee on Animal Use of the Federal University of Tocantins (CEUA-UFT) under process $n^{\circ} 23101.002369 / 2014-28$. The municipality of Araguaínais located in the northern region of the state of Tocantins, at the geographical coordinates $7^{\circ} 10^{\prime} 31^{\prime \prime} \mathrm{S}$ and $48^{\circ} 20^{\prime} 28^{\prime \prime} \mathrm{W}$ and $236 \mathrm{~m}$ of altitude. According to Köppen (1948), the regional climate is classified as Aw (warm and humid), with a mean temperature of $28{ }^{\circ} \mathrm{C}$ and mean annual precipitation of $1800 \mathrm{~mm}$. The meteorological data during the experimental period are shown in Figure 1. 


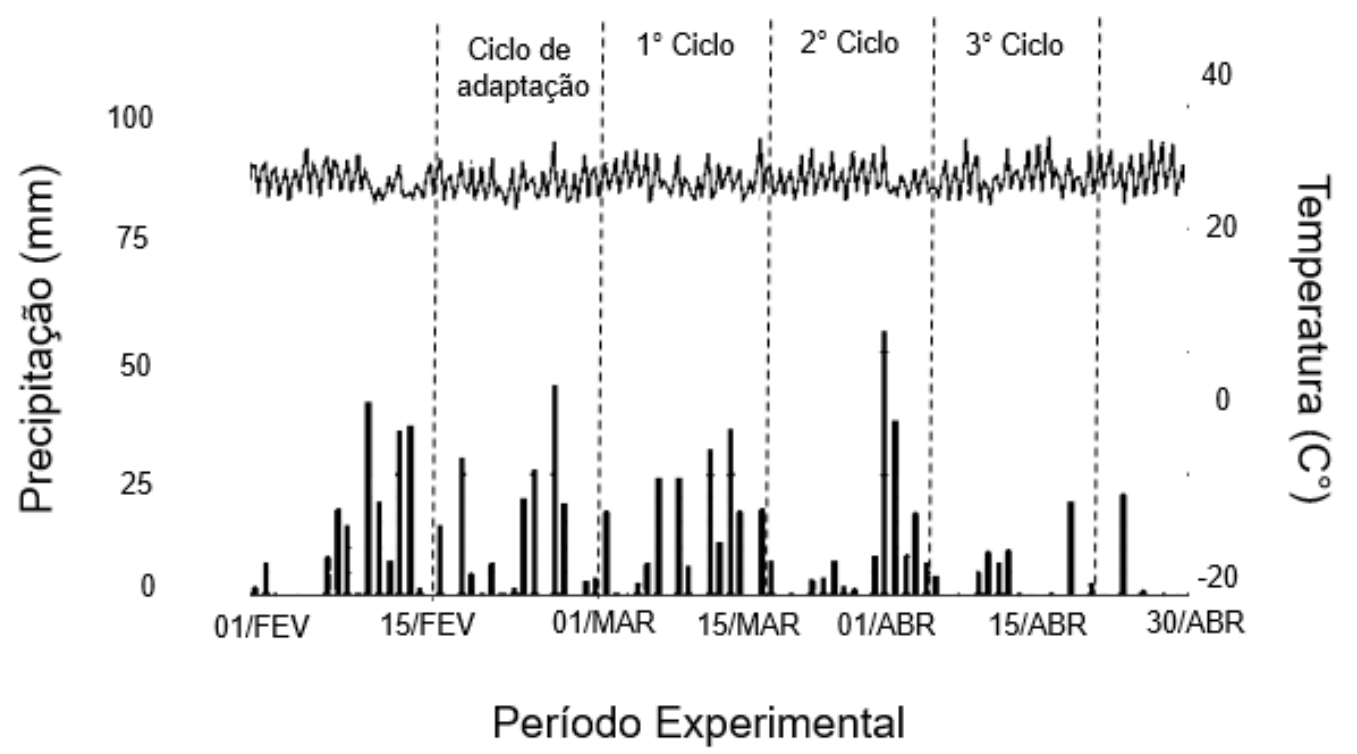

Figure 1. Daily data of precipitation $(\mathrm{mm})$ and temperature $\left({ }^{\circ} \mathrm{C}\right)$ in Araguaína, Tocantins, Brazil, during the experimental period, obtained from the Araguaína-A021 meteorological station (INMET, 2018).

Precipitation (mm); Temperature $\left({ }^{\circ} \mathrm{C}\right)$; Experimental period. Adaptation cycle; 1 st cycle; 2nd cycle; 3rd cycle. Feb.; Mar.; Apr.

The experiment was installed in an area of $4,816 \mathrm{~m}^{2}$ already formed of Massai grass on a Typic Orthic Quartzarenic Neosol (EMBRAPA, 2013), located in the sheep sector of EMVZ/UFT.

The area was divided into 16 paddocks of $301 \mathrm{~m}^{2}$.Four paddocks were used for each of the three treatments, where the rotational stocking method of animals was applied. Each paddock was fenced with screens for sheep to make sure the animals were maintained in the area until the post-grazing height was reached. Twelve paddocks were used to carry out four grazing cycles, the first of them being the adaptation cycle. Four paddocks were reserved and maintained at heights of 45 and $35 \mathrm{~cm}$ (two paddocks for each height) to be used if the experimental paddocks did not return to their initial heights after the rest period. A reserve paddock was not used for the $25 \mathrm{cmheightbecause}$ the adaptation cycle showed that the rest period was sufficient to return to the initial height. Each cycle was finished as soon as the sheep returned to the first paddock.

Initially, a standardization cut was carried out at $15 \mathrm{~cm}$ from the soil with a brushcutter at the first paddocks of each treatment. For the other paddocks, it was carried out every four days to avoid that all of them reached the defined heights at the same moment.

At two days after standardization cut, the area was fertilized using $250 \mathrm{~kg} \mathrm{Nha}^{-1}$ year ${ }^{-1}, 50 \mathrm{~kg} \mathrm{P}_{2} \mathrm{O}_{5} \mathrm{ha}^{-1}$ year $^{-1}$, and $100 \mathrm{~kg}$ $\mathrm{K}_{2} \mathrm{O}$ ha $^{-1}$ year ${ }^{-1}$, considering seven months of rainy season in the year and using as sources urea, single 
superphosphate, and potassium chloride, respectively. $\mathrm{N}$ was divided into four parts and applied at the beginning of each grazing cycle (adaptation and experimental). Fertilizer doses were defined according to a previous experiment of nitrogen and potassium fertilization carried out in the area to ensure amean yield of $5500.00 \mathrm{~kg}$ $\mathrm{DMha}^{-1}$ of Massai grass (SILVA et al., 2017).

Eighteen Dorper x nondescript crossbred sheep (six females and twelve intact males), with a mean weight of $24 \mathrm{~kg} \pm$ (4) and six months of age were tested. Sheep were previously identified with numbered earrings, weighted, dewormed, divided into groups with the same number of males and females to remove the effect of sex, and distributed in three treatments. The rotational stocking method with a fixed rest period of 12 days and 4 days of occupation was adopted. Before the entry of animals into the area, animal stocking was estimated to ensure a reduction of approximately $50 \%$ of the initial forage height. The rest time to be fixed was considered in this period, being enough for height recovery. It was possible because the experimental time was not long enough for great climate changes. Regulating animals, intact sheep, were used at plots of treatments that needed to remove more mass (45 and $35 \mathrm{~cm}$ ) to standardize grazing periods. The stocking rate was defined during the adaptation period by considering the number of animals needed for each treatment.

Sheep were maintained on pasture during the day (between 6 and $18 \mathrm{~h}$ ). After this period, the animals were taken to stalls separate by treatment to avoid predator attacks during the night, during which time no food was available. Whether on pasture or in stalls, animals had free access to water and mineral mix (135 to $150 \mathrm{~g} \mathrm{~kg}^{-1} \mathrm{Ca}, 65 \mathrm{~g} \mathrm{~kg}^{-1} \mathrm{P}, 107 \mathrm{~g} \mathrm{~kg}^{-1}$ $\mathrm{Na}, 12 \mathrm{~g} \mathrm{~kg}^{-1} \mathrm{~S}, 30 \mathrm{~g} \mathrm{~kg}^{-1} \mathrm{CP}, 100 \mathrm{gkg}^{-1}$ TDN).

Forage canopy height was controlled during grazing and after the animals left the area until the beginning of the next cycle. The control was performed every two days by taking 20 measurements at random points at each paddock with a ruler in centimeters from the tiller base, close to the ground, to the midpoint of the highest canopy leaves.

Animal behavior was performed during the second and third assessment cycles at the entrance and exit of animals from paddocks, totaling four days of observation. Four trained observers carried out observations during 12 hours (6 to $18 \mathrm{~h}$ ), the time in which the animals were on pasture. The animals were painted with yellow and black spray paint depending on the animal color to facilitate visualization by evaluators. The variables were individually measured in the animals every ten minutes by recording the grazing, rumination, and other activities. Observations were extrapolated to minutes day ${ }^{-1}$ and grouped into three periods of the day ( 6 to $10 \mathrm{~h}, 10$ to $14 \mathrm{~h}$, and 14 to $18 \mathrm{~h}$ ). The time spent for rumination of each food bolus, the time required to make ten bites, the bite rate (bites $\min ^{-1}$ ), and the number of ruminating chews (chews needed for rumination of each food bolus) were counted with a digital timer. Eight observations were carried out for each variable, i.e., four in the morning and four in the afternoon. The bite rate was considered as the time spent by the animals to perform 20 bites (PENNING \& RUTTER, 2004).

The meteorological data were obtained in the assessment periods and overall mean

\section{Animal Production and Environment}


Rev. Bras. Saúde Prod. Anim., Salvador, v.20, 01 - 12, e0152019, 2019 http://dx.doi.org/10.1590/S1519-9940200152019

at each day of behavior assessment (Table

$1)$.

Table 1. Temperature, air humidity, radiation, and precipitation of behavior assessment days obtained from Araguaína-A021 meteorological station in Araguaína, TO (INMET, 2018)

\begin{tabular}{|c|c|c|c|c|c|c|}
\hline \multirow{2}{*}{ Day } & \multicolumn{3}{|c|}{ Temperature $\left({ }^{\circ} \mathrm{C}\right)$} & \multirow{2}{*}{ Daily mean } & \multirow{2}{*}{$\begin{array}{c}\text { Radiation } \\
\left(\mathrm{kJ} \mathrm{m}^{-2}\right)\end{array}$} & \multirow{2}{*}{$\begin{array}{l}\text { Precipitation } \\
(\mathrm{mm})\end{array}$} \\
\hline & Mean & Minimum & Maximum & & & \\
\hline 03/16/17 & & & & 25.9 & 815.1 & 11.0 \\
\hline $6-10 \mathrm{~h}$ & 23.1 & 22.9 & 23.4 & & & \\
\hline $10-14 \mathrm{~h}$ & 25.0 & 22.8 & 27.4 & & & \\
\hline $14-18 \mathrm{~h}$ & 29.5 & 26.9 & 31.3 & & & \\
\hline $03 / 20 / 17$ & & & & 26.4 & 765.5 & 18.0 \\
\hline $6-10 \mathrm{~h}$ & 22.1 & 21.6 & 22.7 & & & \\
\hline $10-14 \mathrm{~h}$ & 27.9 & 22.1 & 31.7 & & & \\
\hline $14-18 \mathrm{~h}$ & 29.3 & 26.7 & 31.1 & & & \\
\hline $04 / 17 / 17$ & & & & 25.9 & 527.3 & 0.4 \\
\hline $6-10 \mathrm{~h}$ & 22.5 & 22.1 & 23.1 & & & \\
\hline $10-14 \mathrm{~h}$ & 27.9 & 22.7 & 32.1 & & & \\
\hline $14-18 \mathrm{~h}$ & 27.2 & 26.9 & 28.0 & & & \\
\hline $04 / 20 / 17$ & & & & 25.7 & 691.7 & 0.0 \\
\hline $6-10 \mathrm{~h}$ & 21.9 & 21.7 & 22.3 & & & \\
\hline $10-14 \mathrm{~h}$ & 24.7 & 22.1 & 27.3 & & & \\
\hline $14-18 \mathrm{~h}$ & 30.5 & 29.3 & 31.6 & & & \\
\hline Mean & 22.4 & 26.4 & 29.1 & 25.9 & 699.9 & \\
\hline
\end{tabular}

The experimental design was a completely randomized design with six replications (animals) per treatment, repeated over time within the periods of the day. Statistical analyses were performed using the Statistical Analysis System (SAS, 1999), initially analyzing the normality (Shapiro-Wilk) and homoscedasticity (Levene) assumptions. The data were then submitted to analysis of variance and the Tukey's test, being considered significant values of probability lower than $5 \%(\mathrm{P}<0.05)$.

The adopted statistical model was:

$\mathrm{Y}_{\mathrm{ijk}}=\mu+\mathrm{T}_{\mathrm{i}}+\gamma_{\mathrm{i}}+\mathrm{P}_{\mathrm{j}}+(\mathrm{T} \times \mathrm{P})_{\mathrm{ij}}+\varepsilon_{\mathrm{ij}}$ where $\mu$ is the overall mean, $T_{i}$ is the effect of the treatment $\mathrm{i}(\mathrm{i}=45,35$, and 25 $\mathrm{cm}), P_{j}$ is the effect of period of day $\mathrm{j}(\mathrm{j}=$ $1,2$, and 3$),(\mathrm{T} \times \mathrm{P})_{\mathrm{ij}}$ is the effect of the treatment $\times$ period interaction, and $\varepsilon_{\mathrm{ij}}$ is the random error corresponding to the observation $\mathrm{Y}_{\mathrm{ijk}}$.

\section{RESULTS AND DISCUSSION}

An interaction was observed between treatments and periods of the day for grazing and rumination times. For the other activities, a significant difference was observed for treatments and period (b)f the day, separately (Table 2).

\section{Animal Production and Environment}


Rev. Bras. Saúde Prod. Anim., Salvador, v.20, 01 - 12, e0152019, 2019 http://dx.doi.org/10.1590/S1519-9940200152019

Table 2. Times of grazing, rumination, and other activities of sheep on Massai grass pasture as a function of pre-grazing heights. Mean of four days

\begin{tabular}{|c|c|c|c|c|c|c|c|c|}
\hline \multicolumn{9}{|c|}{ Grazing (min) } \\
\hline \multirow{2}{*}{$\begin{array}{c}\text { Pre-grazing } \\
\text { height }\end{array}$} & \multicolumn{3}{|c|}{ Period } & \multirow{2}{*}{ Mean } & \multicolumn{3}{|c|}{$\operatorname{Pr}>F$} & \multirow{2}{*}{$\frac{\mathrm{CV}}{(\%)}$} \\
\hline & $6-10 \mathrm{~h}$ & $10-14 \mathrm{~h}$ & $14-18 \mathrm{~h}$ & & $\mathrm{~T}^{1}$ & $\mathrm{P}^{2}$ & $\mathrm{~T} \times \mathrm{P}^{3}$ & \\
\hline $45 \mathrm{~cm}$ & $240 \mathrm{Aa}$ & $240 \mathrm{Aa}$ & $123 \mathrm{Ab}$ & 201 & \multirow{4}{*}{0.0003} & \multirow{4}{*}{$<.0001$} & \multirow{4}{*}{0.0026} & \multirow{4}{*}{16.92} \\
\hline $35 \mathrm{~cm}$ & $240 \mathrm{Aa}$ & $217 \mathrm{Cb}$ & $90 \mathrm{Bc}$ & 182 & & & & \\
\hline $25 \mathrm{~cm}$ & $235 \mathrm{Aa}$ & $230 \mathrm{Ba}$ & $112 \mathrm{Ab}$ & \multirow[t]{2}{*}{192} & & & & \\
\hline Mean & 238 & 229 & 104 & & & & & \\
\hline \multicolumn{9}{|c|}{ Rumination (min) } \\
\hline Pre-grazing & \multicolumn{3}{|c|}{ Period } & \multirow{2}{*}{ Mean } & \multicolumn{3}{|c|}{$\operatorname{Pr}>F$} & $\mathrm{CV}$ \\
\hline height & $6-10 \mathrm{~h}$ & $10-14 \mathrm{~h}$ & $14-18 \mathrm{~h}$ & & $\mathrm{~T}$ & $\mathrm{P}$ & $\mathrm{T} \times \mathrm{P}$ & $(\%)$ \\
\hline $45 \mathrm{~cm}$ & $0 \mathrm{Ab}$ & $\mathrm{OBb}$ & $65 \mathrm{Aa}$ & 22 & \multirow{4}{*}{0.0414} & \multirow{4}{*}{$<.0001$} & \multirow{4}{*}{$<.0001$} & \multirow{4}{*}{22.34} \\
\hline $35 \mathrm{~cm}$ & $0 \mathrm{Ab}$ & $17 \mathrm{Aa}$ & $22 \mathrm{Ba}$ & 13 & & & & \\
\hline $25 \mathrm{~cm}$ & $3 \mathrm{Ab}$ & $5 \mathrm{Bb}$ & $15 \mathrm{Ba}$ & 8 & & & & \\
\hline Mean & 1 & 8 & 31 & & & & & \\
\hline \multicolumn{9}{|c|}{ Other activities (min) } \\
\hline Pre-grazing & & Period & & \multirow{2}{*}{ Mean } & \multicolumn{3}{|c|}{$\operatorname{Pr}>F$} & $\mathrm{CV}$ \\
\hline height & $6-10 \mathrm{~h}$ & $10-14 \mathrm{~h}$ & $14-18 \mathrm{~h}$ & & $\mathrm{~T}$ & $\mathrm{P}$ & $\mathrm{T} \times \mathrm{P}$ & $(\%)$ \\
\hline $45 \mathrm{~cm}$ & 0 & 0 & 52 & 17B & \multirow{4}{*}{0.0119} & \multirow{4}{*}{$<.0001$} & \multirow{4}{*}{0.3630} & \multirow{4}{*}{21.25} \\
\hline $35 \mathrm{~cm}$ & 0 & 7 & 127 & $45 \mathrm{~A}$ & & & & \\
\hline $25 \mathrm{~cm}$ & 3 & 5 & 112 & $40 \mathrm{~A}$ & & & & \\
\hline Mean & $1 \mathrm{c}$ & $3 b$ & $97 \mathrm{a}$ & & & & & \\
\hline
\end{tabular}

Grazing was the predominant activity from 6 to $10 \mathrm{~h}$ and 10 to $14 \mathrm{~h}$ at the three canopy heights, which corresponded to $93 \%$ of the activities performed by the animals. In fact, most of sheep grazing activity occurs during the day (SIQUEIRA \& FERNANDES, 2014) due to the diurnal management adopted during its evolutionary period to avoid predator attacks (POMPEU et al., 2009).Also, animals remained at rest and rumination at night, returning to grazing during the day, which would explain the predominance of this activity by the animals until $14 \mathrm{~h}$.

Between 6 and $10 \mathrm{~h}$, the grazing period was similar for the canopy heights of 25 to $45 \mathrm{~cm}$. According to Lima et al. (2014), the main grazing moments begin at dawn and, according to Pompeu et al. (2009), the behavior of ruminants on pasture is characterized by long periods of feeding, mainly in the early morning and late afternoon, decreasing other activities, such as rumination, in these periods. This behavior resembles that observed in this study since rumination was lower in the early morning, regardless of the treatment.

Grazing period varied between the three treatments from 10 to $14 \mathrm{~h}$. Although still as a predominant activity, the longer time at the height of $45 \mathrm{~cm}$ may be associated with the beginning of selectivity. The intermediate time at the height of $25 \mathrm{~cm}$ is associated with the higher bite rate required for the food bolus formation (Table 3).

\section{Animal Production and Environment}

Received on: 14/12/2018. Accepted on: 09/04/2019 
Rev. Bras. Saúde Prod. Anim., Salvador, v.20, 01 - 12, e0152019, 2019 http://dx.doi.org/10.1590/S1519-9940200152019

Table 3. Ingestive behavior of sheep on Massai grasspasture as a function of pre-grazing height. Mean of four days

\begin{tabular}{|c|c|c|c|c|c|c|c|}
\hline \multicolumn{8}{|c|}{ Time to perform 10 bites (sec) } \\
\hline \multirow{2}{*}{$\begin{array}{l}\text { Pre-grazing } \\
\text { height }\end{array}$} & \multicolumn{2}{|c|}{ Period } & \multirow{2}{*}{ Mean } & \multicolumn{3}{|c|}{$\operatorname{Pr}>\mathrm{F}$} & \multirow{2}{*}{$\begin{array}{l}\mathrm{CV} \\
(\%)\end{array}$} \\
\hline & Entrance & Exit & & $\mathrm{T}^{1}$ & $\mathrm{P}^{2}$ & $\mathrm{~T} \times \mathrm{P}^{3}$ & \\
\hline $45 \mathrm{~cm}$ & 20.87 & 19.75 & 20.31B & \multirow{4}{*}{$<.0001$} & \multirow{4}{*}{0.1194} & \multirow{4}{*}{0.9742} & \multirow{4}{*}{11.35} \\
\hline $35 \mathrm{~cm}$ & 25.62 & 24.37 & $25.99 \mathrm{~A}$ & & & & \\
\hline $25 \mathrm{~cm}$ & 17.50 & 16.62 & \multirow[t]{2}{*}{$17.06 \mathrm{C}$} & & & & \\
\hline \multirow[t]{2}{*}{ Mean } & 21.33 & 20.24 & & & & & \\
\hline & \multicolumn{6}{|c|}{ Rumination of food bolus (sec) } & \\
\hline \multirow{2}{*}{$\begin{array}{l}\text { Pre-grazing } \\
\text { height }\end{array}$} & \multicolumn{2}{|c|}{ Period } & \multirow{2}{*}{ Mean } & \multicolumn{3}{|c|}{$\operatorname{Pr}>\mathrm{F}$} & \multirow{2}{*}{$\begin{array}{l}\mathrm{CV} \\
(\%)\end{array}$} \\
\hline & Entrance & Exit & & $\mathrm{T}$ & $\mathrm{P}$ & $\mathrm{T} \times \mathrm{P}$ & \\
\hline $45 \mathrm{~cm}$ & 38.00 & 38.08 & \multicolumn{4}{|l|}{$38.4 \mathrm{~A}$} & \multirow{4}{*}{21.12} \\
\hline $35 \mathrm{~cm}$ & 23.62 & 22.98 & 23.28B & \multirow{3}{*}{$<.0001$} & \multirow{3}{*}{1.0000} & \multirow{3}{*}{1.0000} & \\
\hline $25 \mathrm{~cm}$ & 28.62 & 29.05 & \multirow[t]{2}{*}{$28.83 \mathrm{~B}$} & & & & \\
\hline Mean & 30.08 & 30.03 & & & & & \\
\hline \multicolumn{8}{|c|}{ Number of ruminating chews } \\
\hline \multirow{2}{*}{$\begin{array}{l}\text { Pre-grazing } \\
\text { height }\end{array}$} & \multicolumn{2}{|c|}{ Period } & \multirow{2}{*}{ Mean } & \multicolumn{3}{|c|}{$\operatorname{Pr}>\mathrm{F}$} & \multirow{2}{*}{$\begin{array}{l}\mathrm{CV} \\
(\%)\end{array}$} \\
\hline & Entrance & Exit & & $\mathrm{T}$ & $\mathrm{P}$ & $\mathrm{T} \times \mathrm{P}$ & \\
\hline $45 \mathrm{~cm}$ & 53.21 & 53.65 & \multicolumn{4}{|l|}{$53.43 \mathrm{~A}$} & \\
\hline $35 \mathrm{~cm}$ & 36.25 & 36.76 & 36.50B & & & & 25 \\
\hline $25 \mathrm{~cm}$ & 43.54 & 43.02 & $43.28 \mathrm{~B}$ & 0.0002 & 1.0000 & 1.0000 & 23.55 \\
\hline Mean & 44.33 & 44.46 & & & & & \\
\hline & & & Bite rate & $\left.\min ^{-1}\right)$ & & & \\
\hline Pre-grazing & & & Mean & & $\operatorname{Pr}>F$ & & $\mathrm{CV}$ \\
\hline height & Entrance & Exit & Miean & $\mathrm{T}$ & $\mathrm{P}$ & $\mathrm{T} \times \mathrm{P}$ & $(\%)$ \\
\hline $45 \mathrm{~cm}$ & 29.25 & 30.87 & $30.06 \mathrm{~B}$ & & & & \\
\hline $35 \mathrm{~cm}$ & 23.52 & 24.89 & $24.20 \mathrm{C}$ & & & & \\
\hline $25 \mathrm{~cm}$ & 34.85 & 36.28 & $35.55 \mathrm{~A}$ & $<.0001$ & 0.1676 & 0.9949 & 12.14 \\
\hline Mean & 29.20 & 30.68 & & & & & \\
\hline
\end{tabular}

$\mathrm{CV}=$ coefficient of variation. ${ }^{1}$ Treatments $;{ }^{2}$ Period of the grazing cycle $;{ }^{3}$ Interaction between treatments and periods of the grazing cycle. Means followed by different lowercase letters in the rows and uppercase letters in the columns differ from each other by the Tukey's test at 5\% probabilitylevel.

In the period from 14 to $18 \mathrm{~h}$, the animals in all treatments had a lower time of grazing. It is due to the satiation of animals at the end of the day, which is not associated with the mean, minimum, and maximum temperatures at this time, not exceeding the upper critical temperature of thermal comfort of animals(Table 1). According to Baêta and Souza (1997), the upper critical temperature of thermal comfort is up to $35^{\circ} \mathrm{C}$, corroborating with Oliveira et al. (2011), who assessed sheep on pasture in the semi-arid and observed heat stress in animals when temperatures were close to $40{ }^{\circ} \mathrm{C}$. Calviello et al. (2013) did not observe a reduction in sheep grazing activity even during the warmest time of the day when the thermal amplitude was from 21.88 to $34.60{ }^{\circ} \mathrm{C}$.

Animals from the treatment with a pregrazing height of $35 \mathrm{~cm}$ showed a lower time of grazing in relation to the other treatments in the period from 10 to $18 \mathrm{~h}$. It demonstrates that a lower time was required to meet the nutritional requirements of animals probably because

\section{Animal Production and Environment}


this height had lower fibrous material when compared to the height of $45 \mathrm{~cm}$ and higher mass availability when compared to the height of $25 \mathrm{~cm}$, causing the animals of these treatments to graze for a longer time, even at warmer times.

The best structure and quality of the 35 $\mathrm{cm}$ treatment in relation to the $45 \mathrm{~cm}$ treatment allowed the animals to increase energy intake more quickly due to a lower rumen filling, using this time for rumination and other activities. Ruminants adapt to different feeding conditions by modifying their ingestion parameters to reach the level of intake needed to meet their requirements (HODGSON, 1990).In plants with higher heights, protein content is reduced because there is an increase in cell wall thickness and in the quantity of lignin with an increase of stem production, which is more difficult to be digested and used by animals (VALENTE et al. 2010). Macedo et al. (2015) observed an increased grazing time of goats as the height Marandu grass pasture increased. However, Dias et al. (2014) observed no correlation between feed digestibility and grazing times in steers. This modification in plant structure reported by the mentioned authors is related to the longer grazing time in the $45 \mathrm{~cm}$ treatment since there is a smaller apprehension of mass in the bite due to lower participation of leaves in plant composition, requiring that animals spend more time grazing.

There is a correlation between the increased grazing activity not only with a reduction in quality caused by excessive heights but also with a reduction in forage availability. Pacheco et al. (2013) observed an increased grazing time by cows on pasture when there was a reduction in both the quality and the quantity of supplied pasture. In the present study, a longer grazing time was observed in the $25 \mathrm{~cm}$ treatment when compared to the $35 \mathrm{~cm}$ treatment in the periods from 10 to $14 \mathrm{~h}$ and 14 to $18 \mathrm{~h}$, as there was a higher competition for animals to preferentially select leaves, which are more nutritious. According to Sampaio et al. (2016), there is no correlation between grazing activity and intake since it is believed that this activity is associated with forage conditions. These authors, however, correlated the increase in this activity with a reduction in forage availability. According to them, animals can better select the most nutritious plant part when there is a higher forage availability, meeting their requirements more quickly.

Animals had a more significant rumination in the period from 14 to $18 \mathrm{~h}$, especially those submitted to the $45 \mathrm{~cm}$ treatment. According to Pacheco et al. (2013), this activity associated with grazing time implies a higher energy expenditure and, therefore, its increase is not desired. In a forage with higher height, i.e., with a higher amount of stem, animals need to spend more time ruminating the food due to a lower protein content and higher fiber content since the purpose of this activity is to reduce the particles of the consumed food (SAMPAIO et al., 2016) and favor the best use of the diet by buffering the rumen (DIAS et al., 2014).

As expected, the animals submitted to treatment with a pre-grazing height of 45 $\mathrm{cm}$ had less time for other activities since most of their time was used for food search. There is a correlation between foods with lower digestibility and lower nutritional contribution with a reduction in the time used for other activities (DIAS et al., 2014). In plants with higher heights, as in the $45 \mathrm{cmtreatment}$, higher

\section{Animal Production and Environment}


production of structural material is observed and, therefore, more lignified material, which can also explain this result. Macedo et al. (2015) observed a reduction in the time of other activities in goats as pasture height increased.

The time to performbites, rumination of food bolus, the number of ruminating chews, and the bite rate were modified according to canopy height $(\mathrm{P}<0.05)$, with no interaction with the different periods of the day (Table 3).

The time required to perform the bites was lower in the pre-grazing height of 25 $\mathrm{cm}$, followed by $45 \mathrm{~cm}$. This value is inversely proportional to the bite rate and is associated with the lower forage mass available for food bolus formation.

Animals maintained on pasture with a height of $45 \mathrm{~cm}$ took more time to ruminate each food bolus and, consequently, increased the number of chews. Pastures with higher heights show a higher stem production due to a higher shading in the internal part of clumps (MACEDO et al., 2015), as previously mentioned. The lower amount of leaf mass in relation to the amount of stem mass damages pasture structure and causes effects on the ingestive behavior and grazing efficiency of the animal (DIM et al., 2015). In this sense, defoliations that maintain plants at heights higher to those of the suitable levels for the forage species are harmful to mass production and forage density, impairing food intake (FONTES et al., 2014).

The bite rate was higher for the $25 \mathrm{~cm}$ treatment, evidencing the lower mass density, forage availability, and bite depth at the lower height, increasing grazing time and decreasing intake. Roman et al. (2007) studied sheep on ryegrass pasture with different availabilities and observed

\section{Animal Production and Environment}

Received on: 14/12/2018. Accepted on: 09/04/2019 that the increased bite rate was the main strategy to increase the intake in relation to forage availability variation. For this treatment, the bite rate was higher when compared to that found by Pompeu et al. (2009), who observed a mean of 28 bitesmin $^{-1}$ in sheep exclusively on Tanzania grass pasture, and Poliet al. (2009), who verified 27.43 and 27.30 bitesmin ${ }^{-1}$ for lambs weaned and not weaned on Tifton 85 pasture, respectively.

An increased canopy height rises forage capture efficiency (MACEDO et al., 2015) and the bite rate is reduced with a higher forage availability since the animal manages to increase the bite depth and capture more mass (TEIXEIRA et al., 2011).It was observed in the pre-grazing height of $35 \mathrm{~cm}$, which presented the lowest bite rate, while in the $45 \mathrm{~cm}$ treatment this rate was intermediate probably due to a higher stem quantity, which hinders the animal from achieving a higher bite depth when grazing. Pacheco et al. (2013) verified an increase in the bite rate of cows on pasture with higher participation of stems in the supplied forage and attributed this increase to a reduction in the bite depth by this structural plant part.

Among the tested pre-grazing heights, 35 $\mathrm{cm}$ pastures tended to interfere positively with sheep behavior, which had shorter grazing and rumination times, besides a reduced bite rate, with a possible reduction in the energy expenditure to carry out the activities. Managing pastures with heights higher or lower than $35 \mathrm{~cm}$ leads to energy losses and, consequently, a negative change in the grazing behavior of sheep. 


\section{REFERENCES}

AMORIM, D.S.; SILVA, A.L.; SOUSA, S.V.; SOUSA, P.H.A.A.; LIMA, B.S.L.; REIS, A.L.A. Caracterização e restrições de forrageiras indicadas para diferentes espécies em animais de produção Revisão. Revista Eletrônica Científica, v. 3, n. 1, p. 215-237, 2017.

BAÊTA, F.C.; SOUZA, C.F. Ambiência em instalações rurais e conforto térmico. Viçosa:UFV, 1ed., 1997, 246p.

CALVIELLO, R.F.; TITTO, C.G.; AMADEU, C.C.B.; TITTO, E.A.L. Avaliação do comportamento de ovelhas em pastejo durante 24 horas. Revistas Brasileira de Zoociências, v. 15, n. 1,2,3, p. 139-145, 2013.

DIAS, D.L.S.; SILVA, R.R.; SILVA, F.F.; CARVALHO, G.G.P.; BRANDÃO, R.K.C.; SOUZA, S.O.; GUIMARÃES, J.O.; PEREIRA, M.M.S.; COSTA, L.S. Correlação entre digestibilidade dos nutrientes e o comportamento ingestivo de novilhos em pastejo. Archivos de Zootecnia, v. 63, n. 244, p. 645-656, 2014.

DIM, V.P.; ALEXANDRINO, E.; SANTOS, A.C.; MENDES, R.S.; SILVA, D.P. Características agronômicas, estruturais e bromatológicas do capim Piatã em lotação intermitente com período de descanso variável em função da altura do pasto. Revista Brasileira de Saúde e Produção Animal, v. 16, n. 1, p. 10-22, 2015.

EMPRESA BRASILEIRA DE PESQUISA AGROPECUÁRIA EMBRAPA. Sistema brasileiro de classificação de solos. Brasília: EMBRAPA-CNPS, 3ed., 2013. 353 p.

FONTES, J.G.G.; FAGUNDES, J.L.; BACKES, A.A.; BARBOSA, L.T.; CERQUEIRA, E.S.A.; SILVA, L.M.; MORAIS, J.A.S.; VIEIRA, J.S. Acúmulo de massa em cultivares de Brachiaria brizantha submetida a intensidades de desfolhação. Semina: Ciências Agrárias, v. 35, n. 3, p. 1425-1438, 2014.

HODGSON, J. Grazing management: Science into practice. Longman Scientific \& Technical. London, 1990. 203p.

\section{INSTITUTO NACIONAL DE} METEOROLOGIA - INMET. 2012. Rede de Estações Climatológicas. Instituto Nacional de Metereologia.

\section{KÖPPEN, W. Climatologia:}

Conunestudio de lós climas de La tierra. FCE, México, 1948.

LEMPP, B.; SOUZA, F.H.D.; COSTA, J.C.G.; BONO, J.A.M; VALÉRIO, J.R.; JANK, L.; MACEDO, M.C.M.; EUCLIDES, V.B.P; SAVIDAN, Y.H. Capim Massai (Panicummaximum cv. Massai): alternativa para diversificação de pastagem. Comunicado Técnico 69: Embrapa Gado de Corte, 2001. 5p.

LIMA, C.B.; COSTA, T.G.P.; NASCIMENTO, T.L.; LIMA JÚNIOR, D.M.; SILVA, M.J.M.S.; MARIZ, T.M.A. Comportamento ingestivo e respostas fisiológicas de ovinos em pastejo no semiárido. Journal Animal Behavior Biometeorology, v. 2, n. 1, p. 26-34, 2014. 
MACEDO, E.O.; OLIVEIRA, M.E.;

SILVA, P.C.; RIBEIRO, A.M.;

OLIVEIRA, G.L.; ANDRADE, A.C.; RODRIGUES, M.M. Consumo e comportamento ingestivo de cabras em pasto de capim-marandu. Semina:

Ciências Agrárias, v. 36, n. 3 (supl.1), p. 2175-2184, 2015.

OLIVEIRA, P.T.L.; TURCO, S.H.N.; VOLTOLINI, T.V.; ARAÚJO, G.G.JL.; PEREIRA, L.G.R.; MISTURA, C.; MENEZES, D.R. Respostas fisiológicas e desempenho produtivo de ovinos em pasto suplementados com diferentes fontes proteicas. Revista Ceres, v. 58, n. 2, p. 185-192, 2011.

PACHECO, R.F.; FILHO, D.C.A.; BORANDINI, I.L.; RESTLE, J.; PIZZUTI, L.A.D.; CATTELMAN, J. Parâmetros comportamentais de vacas de descarte em pastagens de milheto ou capim Sudão. Ciência Animal

Brasileira, v. 14, n. 3, p. 323-331, 2013.

PIAZZETTA, H.V.L.; MONTEIRO, A.L.G.; RIBEIRO, T.M.D.; CARVALHO, P.C.F.; DITTRICH, J.R.; SILVA. C.J.A. Comportamento ingestivo de cordeiros em terminação a pasto. Acta Scientiarum Animal Sciences, v. 31, n. 3, p. 227-234, 2009.

POLI, C.H.E.C.; MONTEIRO, A.L.G.; BARROS, C.S.; DITTRICH, J.R.; FERNANDES, S.R.; CARVALHO, P.C.F. Comportamento ingestivo de cordeiros em três sistemas de produção em pastagem de Tifton 85. Acta Scientiarum Animal Sciences, v. 31, n. 3, p.235-241, 2009.

POMPEU, R.C.F.F.; ROGÉRIO, M.C.P.; CÂNDIDO, M.J.D.; NEIVA, J.N.M.; GUERRA, J.L.L.; GONÇALVES, J.S.
Comportamento de ovinos em capim tanzânia sob lotação rotativa com quatro níveis de suplementação concentrada.

Revista Brasileira de Zootecnia, v. 38, p. 374-383, 2009.

PENNING, P. D.; RUTTER, S. M. Ingestivebehavior. In: PENNING, P.D. (Ed.). Herbageintake handbook. Reading: The British Grassland Society, 2004.191p.

ROMAN, J.; ROCHA, M.G.; PIRES, C.C.; ELEJALDE, D.A.G.; KLOSS, M.G.; OLIVEIRA NETO, R.A. Comportamento ingestivo e desempenho de ovinos em pastagem de azevém anual (Loliummultiflorum Lam.) com diferentes massas de forragem. Revista Brasileira de Zootecnia, v. 36, n. 4, p. 780-788, 2007.

SAMPAIO, A.F.; MENDES, F.B.L.; SANTANA JÚNIOR, H.A.; SANTANA, E.O.C.; SILVA, R.R.; SILVA, F.F. Correlação entre comportamento ingestivo e consumo de nutrientes em vacas a pasto. Revista Científica de Produção Animal, v. 18, n. 2, p. 110120, 2016.

SANTOS, M.M.; AZEVEDO, M.; COSTA, L.A.B.; SILVA FILHO, F.P.; MODESTO, E.C.; LANA, A.M.Q. Comportamento de ovinos da raça Santa Inês, de diferentes pelagens, em pastejo.

Revista Acta Scientiarum Animal Sciences, v. 33, n. 3, p. 287-294, 2011.

SAS INSTITUTE. SAS/STAT ${ }^{\mathrm{TM}}$. User's guide statistics. 6.4 ed. SAS Institute, Cary, NC, USA, 1999.

SILVA, T.V.S.; SOUSA, L.F.; SANTOS, A.C.; FERREIRA, A.C.H.; CARDOSO, 
Rev. Bras. Saúde Prod. Anim., Salvador, v.20, 01 - 12, e0152019, 2019

R.R.; SOUSA, J.T.L.; JARDIM, W.C.; RICARDO, A.S.; ALMEIDA, J.S.;

CARVALHO, J.B. Nutritional quality of Massai grass fertilized with phosphorus and nitrogen and its influence on intake and weight gain of sheep under rotational grazing on quartzipsamment soil.

Semina: Ciências Agrárias, v. 38, n. 3, p. 1417-1428, 2017.

SIQUEIRA, E.R.; FERNANDES, S. Comportamento e bem-estar de ovinos em pastagens. In: SELAIVE, A.B.; OSÓRIO, J.C.S. Produção de Ovinos no Brasil. 1ed., São Paulo: Roca, 2014. cap.27, p.379-395.

TEIXEIRA, F.A.; BONOMO, P.; PIRES, A.J.V.; SILVA, F.F.; MARQUES, J.A.; SANTANA JÚNIOR, H.A. Padrões de deslocamento e permanência de bovinos em pastos de Brachiaria decumbens diferidos sob quatro estratégias de adubação. Revista Brasileira de Zootecnia, v. 40, n. 7, p. 1489-1496, 2011.

VALENTE, B.S.M.; CÂNDIDO, M.J.D.; CUTRIM JUNIOR, J.A.A.; PEREIRA, E.S; BOMFIM, M.A.D.; FEITOSA, J.V. Composição químicobromatológica, digestibilidade e degradação in situ da dieta de ovinos em capim-tanzânia sob três frequências de desfolhação. Revista Brasileira de Zootecnia, v. 39, p. 113120, 2010.

ZANINI, G.D.; SANTOS, G.T.; SCHMITT, D.; PADILHA, D.A.; SBRISSIA, A.F. Distribuição de colmo na estrutura vertical de pastos de capim Aruana e Azevém anual submetidos a pastejo intermitente por ovinos. Ciência Rural, v. 42, n. 5, p. 882-887, 2012. 